\title{
Indonesia's Diplomacy in Tackling Terrorism Issue at the G-20 Summit in Germany 2017
}

\author{
Ibnu Zulian \\ Program in International Relations \\ University of Potensi Utama Medan \\ Email: Ibnuzulian45@gmail.com
}

\begin{abstract}
The issue of terrorism cannot be separated from international relations; the meeting of President Joko Widodo at the German G-20 Summit brings a distinct impression to the politics of the world, as the head of the diplomacy of quality diplomacy is taken into account because it brings the national interest of Indonesia. Each country has the same concern for combating terrorism as an integrated diplomatic effort.History has proven that arms and military might not eradicate terrorism. The ability of information technology owned by G-20 member countries should be able to be the motor of dissemination of the value of peace.

The author discusses; Indonesia is a plural country, with the largest Muslim population in the world. Indonesia is also the third largest democracy in the world, this unique and strategic position of Indonesia. The commitment in diplomacy to being part of a global effort to combat terrorism and to spread peace and tolerance.The writer found that Germany-20 summit is a good place to find a root cause solution to the issue, among other things, ends inequality and economic injustice. The G-20 as also strengthens cooperation in the field of intelligence.

Keywords: Terrorism; diplomacy; Indonesian's foreign policy;g-20 summit in Germany.
\end{abstract}

\section{INTRODUCTION}

The issue of terrorism cannot be separated from international relations; the meeting of President Joko Widodo at the German G-20 Summit brings a distinct impression to the politics of the world, as the head of the diplomatic quality government is very much considered because it brings the national interest of Indonesia. Diplomatic efforts to integrate the eradication of terrorism with other countries that have the same attention to this issue, History have proven that arms and military might not eradicate terrorism. The ability of information technology owned by G-20 member countries should be able to be the motor of dissemination of the value of peace.

Keywords that form the basis for Indonesian foreign policy, namely foreign policy free active, based on national interests and strengthen identity as a maritime country. Therefore, in the G-20 forum in Hangzhou, China on September 4-5, 2016, President Joko Widodo put forward an active foreign policy strategy based on national interests while strengthening Indonesia's role in the context of global cooperation. But in know 2017 that terrorism became the main focus of Indonesia's diplomacy in 2017 can be said not only talk economy in the G-20 summit in Germany this time. At the G-20 summit meeting in Hamburg, Germany, President Joko Widodo conveyed some of his views on global issues.

According Trunkos that soft power is a superior national resource as the ability of the state that can be used to influence other countries in order to achieve the desired results or interests. Soft power can be realized in the instruments and techniques of foreign policy run by a country. ${ }^{[1]}$ In the discussion on the handling of terrorism, President Jokowi explains the threats that have occurred over the occupation of militant groups, the importance of the G-20 countries to unite, in dealing with the threat of terrorism. For that writer use research question that is why terrorism issue becomes an instrument of diplomacy of the foreign policy of Indonesia?

\section{THEORY APPROACH}

\section{A.Diplomacy}

Diplomacy is an official business activity by sending someone to represent the government. The purpose of diplomacy is to create agreement in the eyes of policy.[2] And another notion that diplomacy is a consideration in the management of international relations. ${ }^{[3]}$ Each Country, regardless of caliber and size, always wants to maintain or expand its position internationally. As the instrument of power that builds political will and strengthens international cooperation. Through diplomatic exchanges promote counterterrorism cooperation with friendly nations that serve our mutual interests, the building capacity that bolsters the capabilities of our allies.[4] Diplomacy helps us take the war to the terrorists, to cut off the resources they need and depend upon survive.

\section{B.Economic Diplomacy}


The globalization of the economy that continues to plague the world increasingly makes the role of economic diplomacy as one of the important instruments in foreign policy. In this context, economic relations between nations can be a glue of political relations.[5] Thus, economic relations can act as influential factors in political relations. Economic globalization has "forced" many countries to study its foreign policy in order to continue to advance the economic life of its people.[6] Indonesia should conduct economic diplomacy in order to maintain the resilience of its national economy, the condition of the Indonesian economy is not spared from the influence of global economic conditions. The resilience of the national economy can be defined as the ability of the national economy in order to fulfill the life of the state. So, in this case, Indonesia must have special steps and efforts in conducting economic diplomacy in order to achieve national economic resilience.

International economic and trade relations of a country play an important role in foreign relations. In fact, contemporary international relations show the need for the necessity of foreign policy. This is to change traditional diplomacy towards multi-sector diplomacy and multi-level..[7] Indonesia currently uses multisector diplomacy that uses the issue of counterterrorism in building the image. In another term a country's essential need for international relations by redefining the meaning of its foreign policy diplomacy. Multilevel diplomacy is also meaningful, economic diplomacy will operate in three ranks: a) bilateral; B) regional; c) multilateral.

C.Public Diplomacy

The development of world situation, actors, and information technology make the direction of diplomacy traditionally shifted to a more modern diplomacy, in this case, public diplomacy. The development of information technology makes the choice of diplomacy tools become diverse. If the previous diplomacy has been colored by issues related to the war, the issue is now shifting. War is not absent, but the emergence of other issues such as environment, tourism, terrorism, health, human rights are being targeted by public diplomacy. ${ }^{\left[{ }^{[3}\right.}$ Public Diplomacy is the effort for a nation to influence public policy or elite opinion of another nation for the purpose of turning the policy of the target nation to advantage.[9]

Diplomacy includes optimizing international communication activities, namely collecting, processing, and disseminating information for the benefit of the state.[10] In line with the statement of former US Secretary of State George Shulz, the raw material of diplomacy is information.[11]Public diplomacy conducted by the Government of Indonesia on the issue of terrorism is triggering a deterrent effect on the issue of terrorism itself. The deterrent effect is perceived as one effective way of tackling or minimizing the space for terrorism. The public opinion formed is that terrorism is a common enemy. The issue that terrorism is common enemy must be pursued through socialization and equate public perception that terrorism is very damaging and destructive to the joints of people's lives. With this case study of Economic diplomacy and Public Diplomacy, the authors hypothesize that Indonesia seeks to combine these two forms of diplomacy in one objective, namely to achieve the national interest from both the economic field and the precise security of terrorism, since these two areas are mutually sustainable.

\section{DISCUSSION}

\section{A.Indonesia's Foreign Policy}

The relationship between diplomacy and foreign policy is closely related. Foreign policy undergoes two stages in the process, namely at the creation level and policy implementation. Diplomacy is one of the instruments in which a decision or policy is implemented. In its broad sense, diplomacy is not only concerned with the implementation level,[12] but also the policymaking process. This is related to the function of diplomacy itself concerning the collection of information, advising on policies, representatives, negotiations, and services of consular services.[13]

Keywords that form the basis for Indonesian foreign policy, namely "foreign policy free active", "based on national interests" and "strengthen identity as a maritime country. Therefore, in the G-20 forum in Hangzhou, China on September 4-5, 2016, President Jokowi put forward an active foreign policy strategy based on national interests while strengthening Indonesia's role in the context of global cooperation. But in know 2017 that terrorism became the main focus of Indonesia's diplomacy in 2017 can be said not only talk economy in the G-20 summit in Germany this time. At the G-20 summit meeting in Hamburg, Germany, President Joko Widodo conveyed some of his views on global issues.

From the Ministry of Foreign Affairs, the direction of Indonesia's foreign policy and strategy one of which is the strengthening of Indonesia's economic diplomacy. Strengthening 
Indonesia's economic diplomacy in bilateral, multilateral, regional and global forums through strategies:[14] 1. Strengthening prospective market diplomacy expansion, 2. Printing formulation Blue role of Indonesia in APEC and G20 to fight for equal and relevant cooperation, 3. Implementation of closer policy coordination among G-20 member countries towards global economic recovery and maintain a robust, sustainable and balanced global economic system 4. Increasing political diplomacy in tandem with economic diplomacy targets 6. ImplementingIndonesia's role in the Regional Comprehensive Economic Partnership (RCEP). 7. Implementing Indonesia's contribution in APEC and G-20 to the struggle for Indonesia's interests in developing countries, the establishment of international norms/regimes that regulate energy and food security as public goods. So it can be said that the direction and strategy of Indonesia's diplomacy policy at least until 2019.

At the praxis level, the foreign policy of a country is the result of a mixture and reflection of domestic politics influenced by the development of the regional and international situation. Indonesia's foreign policy is inseparable from the influence of factors such as strategic geographical position, natural and human resource potential and its demographic order; As well as a sociopolitical system that greatly influences Indonesia's attitude, perspective and way of positioning itself in international forums. ${ }^{[15]}$ It is an appropriate policy if the implementation of foreign policy is directed to the priority of seeking, securing and enhancing the cooperation and support of friendly countries and international bodies.

\section{B.Terrorism Issue as Indonesia's Diplomacy}

Indonesia is a plural country, with the largest Muslim population in the world. Indonesia is also the third largest democracy in the world. This unique and strategic position is Indonesia's commitment to being part of a global effort to combat terrorism and to spread peace and tolerance. Indonesia has always been committed to counterterrorism efforts, including efforts to combat terrorism under the UN framework.

In this regard, Indonesia has an active role in cooperating with United Nations CounterTerrorism Implementation Task Force (CTITF), Terrorism Prevention Branch-United Nations Office on Drugs and Crime (TPB-UNODC), and United Nations Counter-Terrorism Executive Directorate (UNCTED). Furthermore, Indonesia is making efforts to implement 4 (four) pillars of the United Nations Global Counter-Terrorism Strategy (UNGCTS).[16]In 2010, Indonesia hosted the "Workshop on the Regional Implementation of the United Nations Global Counter-Terrorism Strategy in Southeast Asia", in collaboration with UN CTITF. The outcome of the meeting has been reported at the ministerial meeting of the International Counter-Terrorism Focal Points Conference on Addressing Conditions Conducive to the Spread of Terrorism and Promoting Regional Cooperation in Geneva in 2013.

Indonesia's important role in countering international terrorism has been recognized by the United Nations with the re-election of Indonesia as a member of the UN CounterTerrorism Center Advisory Council for the period 2015-2018. Indonesia also underscores the importance of international law in the fight against international terrorism. In this regard, Indonesia has ratified 8 (eight) international conventions relating to counterterrorism that strengthen the national legal framework.

At the national level, Indonesia has a comprehensive strategy for combating terrorism that combines hard and soft approaches. In relation to hard approach, Indonesia has issued Law Number 15 The year 2003 on CounterTerrorism and Law Number 9 The year 2013 on Prevention and Eradication of Terrorism Financing Crime. Furthermore, in order to strengthen efforts to combat terrorism financing, Indonesia has also ratified the Joint Regulation on the Inclusion of Identity of Persons and Corporations in the list of suspected terrorists and terrorist organizations and the unauthorized blocking of funds belonging to persons or corporations listed on terrorist and terrorist suspect lists terrorist.

In relation to soft approach, Indonesia is doing de-radicalization and counterradicalization program. In this regard, Indonesia through its national counter-terrorism agency has launched a de-radicalization blueprint as well as established a center of de-radicalization for terrorist prisoners. Referring to the Blueprint document, the de-radicalization program includes rehabilitation, reintegration, and reeducation for terrorist prisoners by empowering religious leaders and psychologists to provide counter-narratives.[17]

While at the International level, Indonesia is committed to supporting counter-terrorism, including in the fight against terrorism financing. In this regard, Indonesia participates actively as a member of Asia Pacific Group on Money Laundering (APG-ML), as well as members of the 
Steering Group representing countries in Southeast Asia.[18] In addition, for the active role of Indonesian diplomacy, at the FATF Plenary Session held in Brisbane, Australia, 21-26 June 2015, Indonesia has been excluded from the list of countries with strategic weaknesses in antimoney laundering regimes and counterterrorism financing or From the FATF Table 1: The Challenges of Handling Terrorism Cases

\begin{tabular}{|l|l|}
\hline The Challenges of Handling Terrorism Cases \\
\hline Internal & External \\
\hline Public Diplomacy & $\begin{array}{l}\text { Counter-Terrorism Cooperation between } \\
\text { Indonesia and Malaysia }\end{array}$ \\
\hline Interfaith Dialogue & ASEAN-level cooperation \\
\hline Issues legal rules & Cooperation between Indonesia and UNOV \\
\hline
\end{tabular}

Source: Wulan. The Efforts and Challenges of Indonesian Diplomacy on Countering Terrorism Issues in Indonesia.2011. p.30-31

Indonesia also combines the use of hard power, soft power, and smart power.Indonesia embraces soft power through the way of public diplomacy and interfaith dialogue as well as cooperation Table 2: Challenges of Handling Terrorism Cases
International Cooperation Review Group (ICRG) review process. Furthermore, Indonesia through the Center for Financial Transaction Reporting and Analysis (PPATK) has signed a Memorandum of Understanding with the Financial Intelligence Unit (FIU) from 48 countries to strengthen the money laundering and terrorist financing regimes with other countries and regional and international institutions. While Indonesia also issued legal products to enforce strict rules and sanctions against acts of terrorism

\begin{tabular}{|l|l|}
\hline Challenges of Handling Terrorism Cases \\
\hline Internal & External \\
\hline $\begin{array}{l}\text { Instability of the condition of Indonesian } \\
\text { society }\end{array}$ & $\begin{array}{l}\text { Instability of the condition of Indonesian } \\
\text { society }\end{array}$ \\
\hline $\begin{array}{l}\text { The quality and capability of Indonesian } \\
\text { diplomacy }\end{array}$ & $\begin{array}{l}\text { The quality and capability of Indonesian } \\
\text { diplomacy }\end{array}$ \\
\hline Social-Cultural Diversity of Indonesian society & Social-Cultural Diversity of Indonesian society \\
\hline $\begin{array}{l}\text { The Fertility of Religious Radicalism in } \\
\text { Indonesia }\end{array}$ & $\begin{array}{l}\text { The Fertility of Religious Radicalism in } \\
\text { Indonesia }\end{array}$ \\
\hline $\begin{array}{l}\text { Efforts to create Indonesia's national image of } \\
\text { terrorism issues }\end{array}$ & $\begin{array}{l}\text { Efforts to create Indonesia's national image of } \\
\text { terrorism issues }\end{array}$ \\
\hline Efforts to moderate Islam & \\
\hline $\begin{array}{l}\text { The efforts of public diplomacy and interfaith } \\
\text { dialogue have not yet covered all groups }\end{array}$ & \\
\hline
\end{tabular}

Source: Wulan. The Efforts and Challenges of Indonesian Diplomacy on Countering Terrorism Issues in Indonesia.2011. p.30-31

As it is known that Indonesia's diplomacy factor in the international world becomes the main support and important priority to realize the need, the ability, the ability, the result and the success of the Indonesian people in overcoming the problems related to terrorism in Indonesia and also the international world. Indonesia's full support for the world's anti-terrorism campaign is inseparable from systemic factors in world issues. The role of Indonesia in its support for combating terrorism is deserved to be recognized. Moreover, Indonesia is clearly and openly following the rules and vision of the mission undertaken by the United Nations that 
Saudi Arabia, South Africa, Turkey, UK, and the USA, As well as the European Union.[19]Indonesia has been a member of the G-20 since 1999. A number of considerations have been the basis of Indonesia's involvement in the G-20 forum. Starting from the experience of overcoming the Asian economic crisis of the late 1990s, Indonesia's resilience in the face of the global economic crisis in 2008; Indonesia position as the world's third largest democracy with the Muslim majority, the fourth most populous nation, and the leader In ASEAN.

In global diplomacy, of course, our focus is on the integration of Indonesia in the G-20.G-20 is an international organization limited to 20 countries with economic growth of more than $5 \%$ per year. Indonesia joined in the G-20 in 2008 . With the joining of Indonesia as the only ASEAN country is a very strategic position because there Indonesia joined together with developed countries of the world such as Britain, China, America, Japan and also other countries.

For Indonesia, the current global economic situation needs to be addressed by taking a proactive stance. Indonesia must prepare itself for the realities of economic growth in Euro zone and other developed countries that will slow down in the relatively long-term. In other words, Indonesia should be able to anticipate the worst possible scenario. President Joko Widodo once stated that the threats were made up in connection with the occupation of militant groups in Marawi, Filipina. The importance of G20 countries to unite, in dealing with the threat of terrorism, such as Tighten supervision and stop the flow of funding to radical groups and

\section{BIBLIOGRAPHY}

${ }^{1}$ Trunkos, Judit. What is Soft Power Capability and How Does it Impact Foreign Policy. Carolina: University of South Carolina. 2013. p. 4-5

${ }^{2}$ Briggs, Ellis.Anatomy of Diplomacy: The Origin and Execution of American Foreign Policy. David McKay Co. 1968. p. 202.

${ }^{3} \mathrm{McDermott}$, Geoffrey. The new diplomacy and its apparatus. The University of Michigan: Plume Press; Ward Lock1973: p. 39.

${ }^{4}$ Cofer Black, Ambassador J. Coordinator for Counterterrorism Diplomacy and the War Against Terrorism Testimony Before the Senate Foreign Relations Committee. Washington, DC. 2003. par. 3. https://20012009.state.gov/s/ct/rls/rm/2003/18795.htm

${ }^{5}$ Prawirta, Agung. Diplomasi Ekonomi Indonesia. Diakses di : kompas.nasional.com. 2008.

${ }^{6}$ Wanto, Herman Rahma.Diplomasi Ekonomi Sebagai Salah Satu Instrumen PentingDalam Politik Luar Negeri. Disunting dari artikel 'Upaya Diplomasi Indonesia terrorists.[20] With the ability of information technology owned by G-20 member countries, the G-20 should be able to be the motor of dissemination of the value of peace. G-20 countries should be able to find a solution to the root of the problem on the issue that, among other things, and the imbalance and economic injustice. The G-20 should also strengthen cooperation in the field of intelligence.

\section{CONCLUSION}

This unique and strategic position is Indonesia's commitment to being part of a global effort to combat terrorism and to spread peace and tolerance. The German G-20 summit is a good place to find a root cause solution to the issue which, among other things, ends inequality and economic injustice. The G-20 should also strengthen cooperation in the field of intelligence. At the national level, Indonesia has a comprehensive strategy for combating terrorism that combines hard and soft approaches. While at the International level, Indonesia is committed to supporting counter terrorism, including in the fight against terrorism financing. In this regard, Indonesia always participates actively.

In its movement, Indonesia tried to combine two forms of diplomacy, namely Economy and Public in the frame of one objective, namely to achieve the national interest both from the economic field and the security of terrorism precisely, because these two fields are mutually sustainable. Global dynamics also play a role in making Indonesia a pro-active country against various problems.

Dalam Mewujudkan Ketahanan Ekonomi Nasional". $2016 . \quad$ Par. 4. http://www.tabloiddiplomasi.org/index.php/2017/03/29/di plomasi-ekonomi-sebagai-salah-satu-instrumenpentingdalam-politik-luar-negeri/

${ }^{7}$ Perwita, Agung Banyu. Diplomasi Ekonomi Indonesia.Guru Besar Ilmu Hubungan Internasional FISIP Universitas Katolik Parahyangan, Bandung. 2008. Par.

http://nasional.kompas.com/read/2008/04/28/01253873/di plomasi.ekonomi.indonesia

${ }^{8}$ Hennida, Citra. Diplomasi Publik dalam Politik Luar Negeri. Departemen Hubungan Internasional, FISIP, Universitaas Airlangga, Surabaya. p. 2

${ }^{9}$ International Studies Perspectives, 5 (1): 55-60. Potter, Evan. (2002-2003). "Canada and the New Public Diplomacy”. International Journal, LVIII, No. 1: 4364.https://arts.uottawa.ca/communication/en/people/potte r-evan-h

${ }^{10}$ Djelatik, Sukarwarsini. Diplomasi antara teori dan praktik. Yogyakarta: Graha Ilmu. 2008. p. 192 
${ }^{11}$ Shulz, George P. Keynote address from the Virtual Diplomasi Conference: The Information Revolution and International Conflict Management" Peacewroks 18 september.

http://www.usip.org/pubs/virtual118.vdip_18html 1997.

${ }^{12}$ White, B. Diplomacy. In: J. Baylis \& S. SmitH (ed ). The Globalization of World Politics: An Introduction to International Relations . New York: Oxford University Press. 1997. p. 257.

${ }^{13}$ ibid.

${ }^{14}$ Kementrian Luar Negeri. Strategi Politik Luar Negeri Indonesia. 2015. http://kemlu.go.id

${ }^{15}$ Teras Diplomasi. 2011.Par. 5-

6http://www.tabloiddiplomasi.org/index.php/2011/02/18/t eras-diplomasi-34/

${ }^{16}$ Kebijakan Isu Khusus Penanggulanagan Terorisme. 2017. Par. 1. http://www.kemlu.go.id/id/kebijakan/isukhusus/Pages/Penanggulangan-Terorisme.aspx par. 1
${ }^{17}$ ibid.

${ }^{18}$ Asia/Pacific Group On Money Laundering Apg 2nd Mutual Evaluation Report On

Indonesia Against The Fatf 40 Recommendations (2003) And 9 Special Recommendations Adopted By The Apg

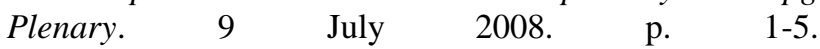
http://www.apgml.org/documents/searchresults.aspx?keywords=indonesia

${ }^{19}$ Peran Indonesia dalam Forum G-20. 2017. Par. 46https://www.ekon.go.id/berita/view/peran-indonesiadalam-forum.3083.html

${ }^{20}$ Peran Indonesia dalam Forum G20. 2017. Par. 2-4. https://www.msn.com/id-id/berita/dunia/inilah-visijokowi-di-ktt-g20/ar-BBE0r6F. 